\title{
Dermatitis Herpetiformis: An Update on Diagnosis and Management
}

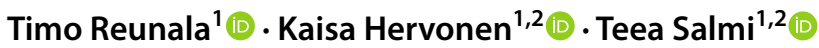

Published online: 11 January 2021

(c) The Author(s) 2021

\begin{abstract}
Dermatitis herpetiformis (DH), presenting with an intense itch and blistering symmetrical rash, typically on the elbows, knees, and buttocks, is a cutaneous manifestation of celiac disease. Though overt gastrointestinal symptoms are rare, threefourths of patients with DH have villous atrophy in the small bowel, and the rest have celiac-type inflammatory changes. DH affects mostly adults and slightly more males than females. The mean age at onset is about 50 years. DH diagnosis is confirmed by showing granular immunoglobulin A deposits in the papillary dermis. The DH autoantigen, transglutaminase 3 , is deposited at the same site in tightly bound immune complexes. At present, the DH-to-celiac disease prevalence is 1:8. The incidence of DH is decreasing, whereas that of celiac disease is increasing, probably because of improved diagnostics. In DH, the treatment of choice for all patients is a gluten-free diet (GFD) in which uncontaminated oats are allowed. At onset, most patients need additional dapsone to rapidly control the rash and itching. Dapsone can be stopped after a mean of 2 years, and a strict lifelong GFD alone is required. Dietary adherence offers an excellent long-term prognosis for patients with $\mathrm{DH}$, with a normal quality of life and all-cause mortality.
\end{abstract}

\section{Dermatitis Herpetiformis Linked to Celiac Disease}

Dermatitis herpetiformis (DH) was described as a dermatological entity by Louis Duhring in 1884, 4 years before Samuel Gee defined the gastrointestinal symptoms of celiac disease [1, 2]. In the 1960s, small bowel biopsies taken from patients with DH showed villous atrophy in most patients, although they had no overt gastrointestinal symptoms [3, 4]. One-fourth of the patients with DH had normal small bowel villous architecture with an increased density of intraepithelial lymphocytes, which was later confirmed to be celiac-type minor enteropathy [5]. The finding of immunoglobulin A (IgA) deposits in the papillary dermis of patients with $\mathrm{DH}$ was of the utmost diagnostic importance [6]. In the 1970s, further findings linking $\mathrm{DH}$ and celiac disease included an identical human leukocyte antigen (HLA) pattern [7], the response of the rash to a glutenfree diet (GFD) [8, 9], and the occurrence of both diseases within families [10]. In the 1990s, genetic studies confirmed

Timo Reunala

timo.reunala@tuni.fi

1 Celiac Disease Research Center, Faculty of Medicine and Health Technology, Tampere University, Tampere, Finland

2 Department of Dermatology, Tampere University Hospital, Tampere, Finland

\section{Key Points}

Dermatitis herpetiformis affects mostly adults, presenting with symmetrical rash and intense itch, mainly on the elbows, knees, and buttocks.

Diagnosis is confirmed by showing granular immunoglobulin A deposits in papillary dermis on immunofluorescence examination.

Gluten-free diet is the treatment of choice for all patients: it slowly heals the rash and subclinical villous atrophy, i.e., celiac disease, in the small bowel.

Strict adherence to a gluten-free diet needs advice from a dietitian, support from family members and celiac disease patient organizations, and leads to excellent longterm prognosis. 
that virtually every patient with DH and celiac disease had the alleles contributing to the HLA-DQ2 or HLA-DQ8 haplotype [11], and even monozygotic twin pairs affected by both phenotypes were found [12].

DH is now known to be a common extraintestinal manifestation of celiac disease occurring in up to $10 \%$ of the celiac disease patient series in Europe and North America [13-15]. Small DH series have also recently been described in Brazil, China, and India [16-18]. The incidence of DH has been shown to be decreasing $[19,20]$, whereas the opposite is true for celiac disease, most likely because of improved awareness of subclinical cases and the wide use of serologic screening [21]. However, why only some undiagnosed celiac individuals develop an itchy blistering rash with dermal IgA deposits, i.e., $\mathrm{DH}$, remains unknown.

During the last 20 years, several important research findings have emerged. A breakthrough in celiac disease research was the discovery by Dieterich et al. [22] in 1997 that tissue transglutaminase (TG2) was the target autoantigen for IgA antibody responses. Five years later, Sárdy et al. [23] showed that epidermal transglutaminase (TG3) was the autoantigen in DH. At present, IgA-class TG3 autoantibodies are known to be produced by plasma cells in the small bowel [24]; they occur in the blood of most patients with $\mathrm{DH}$, are partly bound in the circulating immune complexes, and disappear with a GFD [25, 26]. Importantly, the TG3 enzyme coexists with IgA autoantibodies in the dermal deposits, forming tightly bound immune complexes [27].

\section{Clinical Presentation, Sex, and Age at Diagnosis}

\subsection{Clinical Presentation}

The clinical picture of DH consists of an itchy rash occurring in the favored sites of the elbows, the extensor surfaces of the forearms, the knees, and the buttocks, including the sacral area [28] (Fig. 1). The rash is polymorphic, consisting of small blisters, papules, and erythema; however, because of the intense itch and associated scratching, erosions, crusts, and postinflammatory hyperpigmentation often dominate the clinical picture. The localization of the rash is so typical for DH that the itchy rash in the predominant skin sites usually raises suspicion of DH [29]. However, the severity of the rash varies between individuals, and a more intense rash may also affect other sites, such as the scalp, face, and upper back. The clinical picture and severity of the DH rash seem to have remained unchanged over recent decades [30] without becoming milder or otherwise nonclassical as seen in celiac disease [21, 31]. The itch in DH is very prominent; in half of the patients, it is a constant finding and correlates with common sleep disturbances [32]. Triggering factors such as taking indomethacin and inadvertent dietary iodide ingestion are known to exacerbate the rash and itching [33, 34]. A few cases of localized DH on the face or elsewhere on the body have been described [35]. Acral purpura is a rare finding in DH and may be seen either with the typical rash or as the only symptom of the disease, especially in children with DH $[36,37]$.

The differential diagnosis of DH includes various itchy, excoriated, and blistering skin diseases. Linear IgA disease and sometimes bullous pemphigoid may clinically resemble DH, but immunofluorescence examination easily differentiates these disorders [38, 39]. Other itchy skin diseases, such as scabies, atopic and nummular dermatitis, lichen planus, and urticaria may also resemble $\mathrm{DH}$, but the most obvious difference is the symmetrical distribution of the rash on the favored sites in DH [40].

Despite the highly characteristic clinical picture of DH, familiar to many dermatologists, suspicion for the correct diagnosis is not self-evident in primary care. The mean delay in diagnosis of DH has been reported to be as long as 3.2 years [41]. In recent studies from Finland, one-third of patients with $\mathrm{DH}$ or celiac disease had delays of at least 2 and 10 years, respectively, and the female sex was significantly associated with a delayed diagnosis in both studies [42, 43] (Table 1). Fortunately, the diagnostic delay has shortened in recent years, possibly because the Finnish celiac disease guideline is available online and is open to all physicians [44]. The guideline also describes DH with clinical pictures and provides information on how and where the diagnosis can be made.

\subsection{Sex and Age at Diagnosis}

Earlier studies on DH have shown a clear male predominance, whereas two recent large studies in adults with $\mathrm{DH}$ found the male-to-female ratio to be close to $1: 1[19,20]$ (Table 1). This is in sharp contrast to celiac disease, in which females clearly outnumber males [45]. The female trend also appears to be valid in children with DH [46, 47].

The mean age at diagnosis of DH has been $40-50$ years in larger patient series, with males being somewhat older than females [19, 48-50] (Table 1). The oldest patients have been diagnosed when aged $>80$ years. DH seems to be rare in childhood, occurring in only $4 \%$ in the Finnish series but at a higher percentage in an Italian series [51, 52]. Interestingly, a significant increase in the mean age at diagnosis was reported in a large cohort of patients with DH collected from 1970 onwards in Finland [19]. 


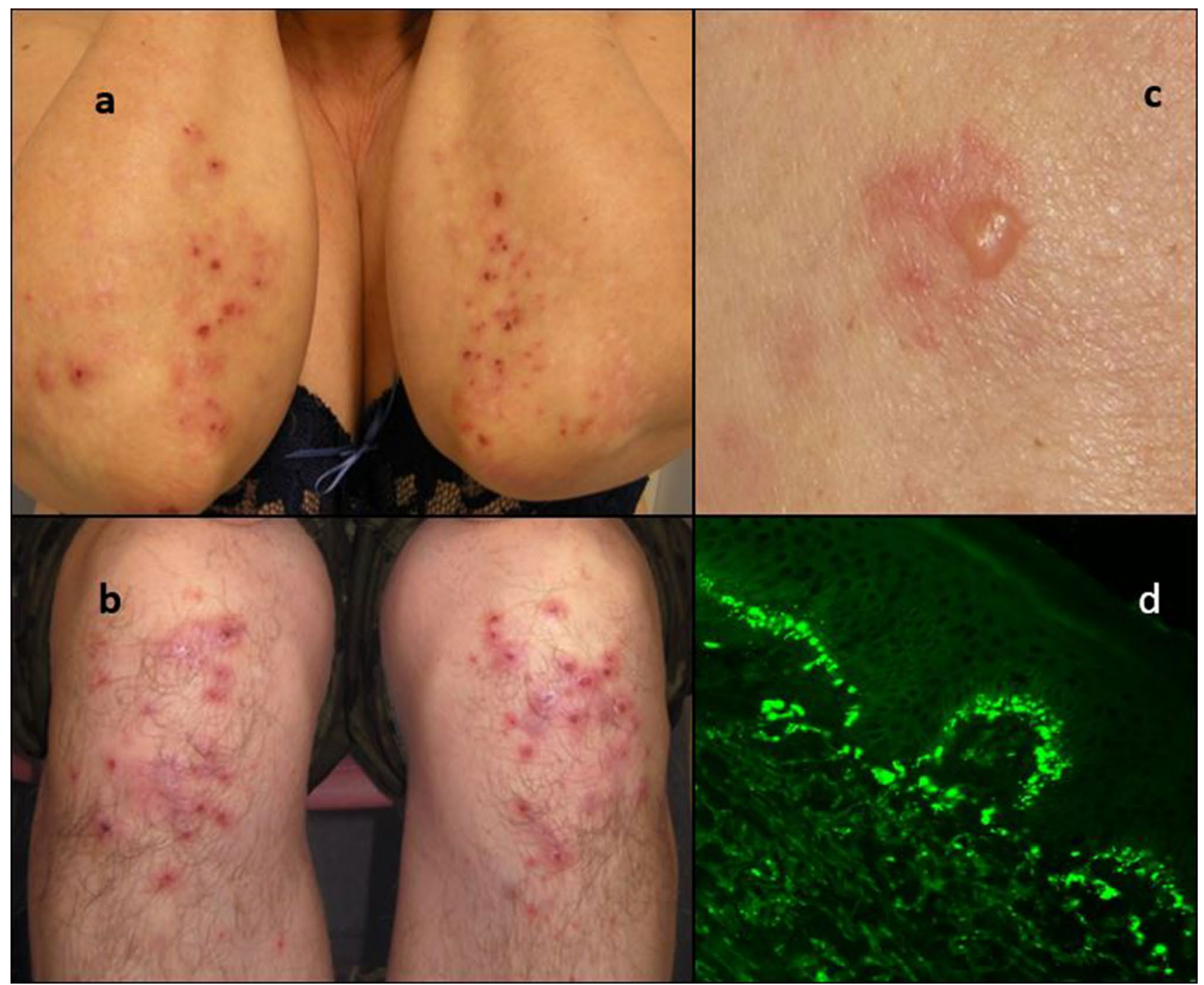

Fig. 1 Dermatitis herpetiformis lesions on the a elbows and $\mathbf{b}$ knees: observe symmetrical distribution and erosions due to scratching. c A close-up view of a small blister. d Direct immunofluorescence finding

The increase was from 35 to 51 years in men and from 36 to 46 years in women. A similar increasing trend has also been observed in celiac disease [45], and one plausible explanation for this is a lower lifetime gluten load. For example, in Finland, the annual consumption of wheat and other gluten-containing cereals per person has decreased from 150 to $71 \mathrm{~kg}$ over the past 50 years [53].

\section{Diagnosis of Dermatitis Herpetiformis}

In $\mathrm{DH}$, granular IgA deposits in the dermal papillae were detected by direct immunofluorescence examination as early as 1969 [6]. Since then, the finding has proven to be highly specific, and a diagnosis of DH should be based of uninvolved skin showing pathognomonic granular immunoglobulin A deposits at the dermo-epidermal junction

on the presence of granular IgA deposits in the papillary dermis [28] (Fig. 1). Skin biopsy should be taken from normal-appearing skin adjacent to the rash, i.e., perilesional skin, because IgA deposits occur in greater amounts near the active lesions [54]. False-negative immunofluorescence results occur in about $5 \%$ of patients and are particularly possible if the biopsy is taken from blisters or inflamed skin. Fibrillar IgA deposits are known to occur particularly in patients in Japan, but these cases seem to differ from classical DH in several aspects [55].

Histopathological findings in DH lesions include neutrophilic micro-abscesses in the dermal papillae with or without subepidermal blistering [56]. However, these are not entirely specific to $\mathrm{DH}$, as similar findings can be detected in other blistering skin diseases, such as 
Table 1 Differences between dermatitis herpetiformis and celiac disease

\begin{tabular}{|c|c|c|}
\hline Variable & Dermatitis herpetiformis & Celiac disease \\
\hline Age at diagnosis & Mainly adults, mean age about 50 years & Children and adults \\
\hline Sex & Slightly more males & Females predominate \\
\hline Delay at diagnosis $[42,43]$ & One-third over 2 years & One-third over 10 years \\
\hline Rash with IgA-TG3 deposits & $100 \%$ & $0 \%$ \\
\hline Small bowel villous atrophy & $75 \%$ & $100 \%^{\mathrm{a}}$ \\
\hline IgA-TG2 autoantibodies in serum $[25,68,69]$ & Up to $86 \%$ & Up to $100 \%$ \\
\hline IgA-TG3 autoantibodies in serum $[25,70]$ & Up to $86 \%$ & Up to $24 \%^{\mathrm{b}}$ \\
\hline Prevalence in Finland and the UK $[19,20]$ & 75 and 30 per 100,000 & 660 and 240 per 100,000 \\
\hline Incidence $[19,20]$ & Decreasing & Increasing \\
\hline Response to a GFD $[8,9,49,74]$ & $\begin{array}{l}\text { Slow; at onset, most patients need additional } \\
\text { dapsone to control the rash and itching }\end{array}$ & $\begin{array}{l}\text { Rapid; days or weeks until gastrointestinal } \\
\text { symptoms resolve }\end{array}$ \\
\hline Long-term prognosis on a GFD $[80,88,97,98]$ & $\begin{array}{l}\text { Excellent; normal quality of life and decreased } \\
\text { all-cause mortality }\end{array}$ & $\begin{array}{l}\text { Decreased quality of life; all-cause and } \\
\text { lymphoma mortality may be increased }\end{array}$ \\
\hline
\end{tabular}

$G F D$ gluten-free diet, $I g A$ immunoglobulin A, $T G 2$ tissue transglutaminase, $T G 3$ epidermal transglutaminase

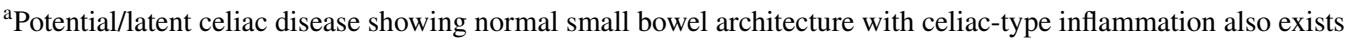

${ }^{\mathrm{b}}$ Data still conflicting

linear IgA disease [57]. A recent DH study showed that the specificity of histologic examination was high (0.95) but the sensitivity was low at only 0.75 [58]. Therefore, a biopsy for histological analysis is not mandatory, because the detection of granular IgA deposits with immunofluorescence examination, together with a compatible clinical picture, are sufficient for a diagnosis of $\mathrm{DH}$ [59]. IgA deposits persist in the dermis for at least a few years after adherence to a GFD [60], so the DH diagnosis can be confirmed afterwards without returning to a normal glutencontaining diet if necessary.

When the patient is known to have celiac disease and has developed skin symptoms, DH is easily suspected [61]. In such cases, histopathological examination of skin lesion helps in correct diagnosis, which often can be a dermatosis other than DH [62]. A recent study described six patients with celiac disease with various inflammatory dermatoses who also showed granular IgA deposits in immunofluorescence specimens [63]. However, no evidence of clinical DH and coexistent TG3 deposits were seen, suggesting that the IgA findings were not representative of typical $\mathrm{DH}$.

\section{Small Bowel Biopsy, Serum Transglutaminase Antibodies, and Family History}

Patients with DH rarely have overt gastrointestinal symptoms typical of classic celiac disease [64]. However, small bowel biopsies obtained during upper gastrointestinal endoscopy revealed villous atrophy and crypt hyperplasia in as many as three-fourths of patients with DH (Table 1). The remaining patients have normal villous structure with inflammatory findings compatible with latent celiac disease, such as intraepithelial lymphocytosis and increased densities of $y \delta+T$ cells [5]. In recent decades, the small bowel mucosal lesion has become less severe in DH [65]. Moreover, the presence or absence of small bowel villous atrophy has no effect on long-term prognosis [66]. As such, there is no need for routine small bowel biopsies when $\mathrm{DH}$ is diagnosed [28, 59].

Circulating IgA-class antibodies against TG2, the autoantigen of celiac disease, are also frequent in untreated patients with DH [67] (Table 1). At present, commercial enzymelinked immunosorbent assay (ELISA)-based TG2-antibody tests are widely used in the screening of celiac disease [68]. In $\mathrm{DH}$, these tests mainly detect patients with villous atrophy [25, 69]. As such, we routinely screen our patients with DH at diagnosis with the TG2-antibody ELISA test to ascertain whether small bowel villous atrophy is present.

IgA-class antibodies against TG3, the autoantigen of $\mathrm{DH}$, exist in the serum of the majority of patients with $\mathrm{DH}$ and in a smaller percentage of those with celiac disease [23, 25, 70] (Table 1). At present, the exact specificity of TG3 antibody measurements for $\mathrm{DH}$ and celiac disease, as well as the most applicable reference values and test kits, are yet to be clarified. Consequently, TG3 antibody testing is not currently routinely applied.

Celiac disease has a well-known tendency to run in families, and $7.5 \%$ of first-degree relatives are affected [71]. A DH study performed in Finland showed that as many as $18 \%$ of the 281 patients had first-degree relatives who were 
affected, and the prevalence among relatives was 3.9\% for celiac disease and $1.5 \%$ for DH [72]. Familial DH cases have also been reported in the USA but rarely elsewhere [73]. Dermatologists should be aware of this possibility and inquire and inform patients about this when DH is newly diagnosed.

\section{Gluten-Free Diet and Dapsone Treatment}

\subsection{Gluten-Free Diet}

A strict lifelong GFD is the basic treatment for $\mathrm{DH}$, and it should be initiated by all patients after the diagnosis is confirmed [74]. A GFD means the permanent avoidance of wheat, barley, rye, and all foods containing these cereals. The safety of oats in DH has been demonstrated in two short-term challenges and one long-term follow-up study $[30,75,76]$; oats are currently allowed as part of a GFD in many countries. However, oats may easily become contaminated by gluten traces from other cereals, and it is important to ensure that only noncontaminated pure oats are used [74]. In Finland, uncontaminated oat products have been available for 20 years, and $82 \%$ of patients with DH on a GFD currently regularly consume oats [30]. Including oats in the diet helps to increase daily fiber consumption. Maintaining a strict GFD requires broad knowledge of all tolerable foods in the diet, so dietary guidance, preferably from a dietitian, should be offered to all patients newly diagnosed with DH [74]. Moreover, education and support from celiac disease patient organizations are important factors in helping patients adhere to and manage the costs of a GFD [77].

Adherence to a strict GFD in DH slowly heals the rash and itching. It may be several weeks to a few months before the symptoms start to alleviate, and total clearance is achieved after a mean of 2 years $[8,9]$ (Table 1 ). The disappearance of deposited IgA and TG3 from the papillary dermis takes even longer, and dermal immune deposits persist even after patients have been asymptomatic for several years on a strict GFD [78]. Overt gastrointestinal symptoms, when present in DH, usually alleviate within a few weeks, and serum IgA-class TG2 autoantibodies disappear within 1-3 years, indicating that the small bowel villous atrophy has healed $[25,79]$. Continuously high or alternating antibody levels during the GFD treatment indicate an ongoing gluten intake, which can be a result of either some unknown faults in the diet or inadequate compliance.

Long-term follow-up of Finnish patients with DH indicated that $>90 \%$ adhere to a GFD, usually strictly $[30,80]$. Importantly, adherence to a GFD normalizes lowered quality of life within 1 year [64]. Recently, 95\% of 19 patients with asymptomatic DH on a long-term GFD who undertook a gluten challenge had a skin or small bowel relapse within
1 year [78]. This confirms that gluten intolerance is a permanent condition, justifying lifelong GFD treatment in all patients with DH.

\subsection{Dapsone}

The majority of patients with $\mathrm{DH}$, especially those with the widespread rash and intense itch, need additional dapsone treatment when starting the GFD. Dapsone is a sulfone drug with potent anti-inflammatory properties [81]. It relieves the itch and the rash in DH within a few days but has no effect on the enteropathy or IgA deposits in the skin. The starting dose in adults is $25-50 \mathrm{mg} / \mathrm{day}$, which is usually enough to control the itch and development of new lesions; if necessary, the dose can gradually be increased up to $100 \mathrm{mg} / \mathrm{day}$. In children, the recommended starting dose of dapsone is $0.5 \mathrm{mg} / \mathrm{kg} / \mathrm{day}$. After the rash has disappeared, the dapsone dose is slowly reduced and finally tapered off as the GFD alone controls the rash. This will take an average of 2 years on a strict GFD $[8,9,49]$. However, response varies, and many patients on a GFD need dapsone for several years. One apparent reason for this is that adherence to a GFD is not strict enough because of some unknown faults in the diet or inadequate compliance. When we examined our prospectively collected large series of patients with $\mathrm{DH}$, we found $16(4 \%)$ patients who still required dapsone though they had been on a GFD for many years [82]. Of these, 12 patients were re-examined, and a thorough dietary assessment revealed major or minor lapses in six. We concluded that only very few patients with $\mathrm{DH}$ whose rash seems to be refractory on a GFD need continuous dapsone treatment.

Dapsone is usually well-tolerated at recommended doses [81]. However, hematological side effects may sometimes occur, the most common being dose-dependent hemolysis and methemoglobinemia. Patients with glucose-6-phosphate dehydrogenase deficiency are more prone to these side effects. Other possible side effects that usually appear within the first 3 months of treatment include headache, dizziness, nausea, elevated transaminases, and even agranulocytosis [81]. Rarely, peripheral neuropathy with primarily motor function loss may develop in patients with DH continuously receiving a daily dose of dapsone $\geq 100 \mathrm{mg}$ [83]. Clinical and laboratory monitoring, including complete blood cell count and liver and renal function tests, are necessary both at baseline and during follow-up of dapsone treatment; these are best performed by a dermatologist. When dapsone is causing major side effects or is otherwise contraindicated, sulfasalazine or rituximab can help [84]. Topical dapsone $5 \%$ gel, available in the USA and Canada, is free from systemic side effects and seems moderately efficient in the treatment of localized DH lesions on the face and chest $[85,86]$. 


\section{Long-Term Prognosis}

\subsection{Malignancies and Mortality}

Lymphoma is the most severe and well-documented complication in celiac disease and DH $[87,88]$. The risk in $\mathrm{DH}$ is increased six to tenfold. Fortunately, the lymphoma risk is evident only during the first 5 years after DH diagnosis and GFD adherence [87]. Lymphomas are of enteropathy-associated T-cell or B-cell origin, and patients not adhering to a GFD are at special risk [89]. Unlike the increased mortality rates reported with celiac disease [88], the mortality rate in $\mathrm{DH}$ is decreased (Table 1). In a Finnish study, 476 patients with $\mathrm{DH}, 98 \%$ of whom adhered to a GFD, were followed-up for a total of 9079 person-years; the results showed a significantly decreased standardized mortality rate $(0.70)$ compared with the general population [80]. A study of 846 patients with $\mathrm{DH}$ from the UK found a slightly — albeit not significantly-lowered mortality rate (hazard ratio 0.93) [90].

\subsection{Associated Autoimmune Disorders}

Associations between DH and other autoimmune diseases must be kept in mind at diagnosis and during the follow-up of patients with DH. Type 1 diabetes mellitus was found in $2.3 \%$ of the 1104 Finnish patients with DH, mostly appearing in childhood or adolescence before the onset of $\mathrm{DH}$; treatment with a combined diabetic diet and GFD was largely successful [91]. Atopic dermatitis is also common in younger people, with a previous study finding it in $20 \%$ of Hungarian and Finnish children with DH [92]. A recent large register study from Finland confirmed this association (odds ratio 10.42) and suggested that the heightened risk of autoimmune diseases with atopic dermatitis could be the reason [93]

Autoimmune thyroid diseases usually appear in older age groups, are more frequent in females, and have been reported in $4.3 \%$ of patients with DH $[94,95]$. These disorders are present at $\mathrm{DH}$ diagnosis or often appear while undertaking a GFD. Vitiligo and alopecia areata are also associated with $\mathrm{DH}$ [95]. A recent register study also linked DH to the risk of bullous pemphigoid [96].

\subsection{Quality of Life}

Most patients with untreated DH experience intense itch and sleep disturbances and may also have gastrointestinal symptoms [32, 64]. As expected, an examination of 52 patients with untreated DH found a significantly reduced quality of life compared with the 64 healthy controls; however, quality of life returned to normal after 1 year when over $90 \%$ of the patients had undertaken a GFD. We also studied quality of life in patients with DH undertaking a long-term GFD. Persistent gastrointestinal symptoms known to occur in treated celiac disease appeared to not affect these patients, and the quality of life paralleled that of controls [97, 98]. In addition, the consumption of oats within the GFD had no effect on quality of life [30].

\section{Concluding Remarks}

$\mathrm{DH}$, presenting with an intense itch and blistering rash, typically on the elbows, knees, and buttocks, is the most common extraintestinal manifestation of celiac disease [13]. Although overt gastrointestinal symptoms are rare, threefourths of patients with $\mathrm{DH}$ have villous atrophy in the small bowel, and the rest have celiac-type inflammatory changes. A valid current hypothesis is that a large undiagnosed and mostly subclinical pool of celiac disease is a prerequisite for the development of DH $[44,53]$. The incidence of $\mathrm{DH}$ is decreasing $[19,20]$, whereas the opposite is true for celiac disease, most likely because of the increased awareness of subclinical cases and wide use of serologic screening [21, 99]. Why only some undiagnosed celiac individuals develop an itchy blistering rash with dermal IgA-TG3 deposits, i.e., $\mathrm{DH}$, remains unknown.

The diagnosis of DH relies on the detection of granular IgA deposits in the dermal papillae in skin biopsy taken from perilesional skin [54]. The DH autoantigen is TG3, which is also deposited in the papillary dermis [23, 27]. Why IgA-TG3 aggregates are also deposited in sites never involved in blister formation, and why they disappear from the skin first after several years of a GFD but reappear rapidly after gluten challenge, remains unclear [78, 100]. In contrast to celiac disease, $\mathrm{DH}$ affects mostly adults and slightly more males. At present, a markedly increased age at diagnosis and less severe small bowel damage in DH [19, 65] suggests changes in environmental factors, such as a lowered lifetime gluten load [53].

A GFD is the treatment of choice in DH, but most patients also initially need additional dapsone to rapidly relieve the itching and blistering. Adherence to a GFD should be strict and exclude all wheat, barley, and rye products; uncontaminated oats are currently allowed [74]. Dietitians and celiac disease patient organizations provide great help when starting the GFD [77]. Following dietary treatment, patients with DH have an excellent long-term prognosis, with a normal quality of life and all-cause mortality [80, 97].

\section{Declarations}

Funding This research was funded by the Academy of Finland and Competitive State Research Financing of the Expert Responsibility area of Tampere University Hospital (grants 9X051 and AA070). 
Conflicts of interest Timo Reunala, Kaisa Hervonen, and Teea Salmi have no conflicts of interest that are directly relevant to the content of this article.

Availability of data and material Not applicable.

Ethics approval Not applicable.

Consent Not applicable.

Author contributions TR wrote the paper, TS and KH commented on the paper, and all authors reviewed the paper.

Open Access This article is licensed under a Creative Commons Attribution-NonCommercial 4.0 International License, which permits any non-commercial use, sharing, adaptation, distribution and reproduction in any medium or format, as long as you give appropriate credit to the original author(s) and the source, provide a link to the Creative Commons licence, and indicate if changes were made. The images or other third party material in this article are included in the article's Creative Commons licence, unless indicated otherwise in a credit line to the material. If material is not included in the article's Creative Commons licence and your intended use is not permitted by statutory regulation or exceeds the permitted use, you will need to obtain permission directly from the copyright holder. To view a copy of this licence, visit http://creativecommons.org/licenses/by-nc/4.0/.

\section{References}

1. Duhring LA. Dermatitis herpetiformis. Landmark article, Aug 30, 1884. JAMA. 1983;250:212-6. https://doi.org/10.1001/ jama.1983.03340020028029.

2. Losowsky MS. A history of coeliac disease. Dig Dis. 2008;26:112-20. https://doi.org/10.1159/000116768.

3. Marks J, Shuster S, Watson AJ. Small-bowel changes in dermatitis herpetiformis. Lancet. 1966;2:1280-2. https://doi. org/10.1016/S0140-6736(66)91692-8.

4. Fry L, Keir P, McMinn RM, Cowan JD, Hoffbrand AV. Smallintestinal structure and function and haematological changes in dermatitis herpetiformis. Lancet. 1967;2:729-33. https://doi. org/10.1016/s0140-6736(67)91942-3.

5. Savilahti E, Reunala T, Mäki M. Increase of lymphocytes bearing the gamma/delta $\mathrm{T}$ cell receptor in the jejunum of patients with dermatitis herpetiformis. Gut. 1992;33:206-11. https://doi. org/10.1136/gut.33.2.206.

6. van der Meer JB. Granular deposits of immunoglobulins in the skin of patients with dermatitis herpetiformis. An immunofluorescent study. Br J Dermatol. 1969;81:493-503. https://doi. org/10.1111/j.1365-2133.1969.tb16024.x.

7. Katz SI, Falchuk ZM, Dahl MV, Rogentine GN, Strober W. HL-A8: A genetic link between dermatitis herpetiformis and gluten-sensitive enteropathy. J Clin Invest. 1972;51:2977-80. https://doi.org/10.1172/JCI107123.

8. Fry L, Seah PP, Riches DJ, Hoffbrand AV. Clearance of skin lesions in dermatitis herpetiformis after gluten withdrawal. Lancet. 1973;1:288-91. https://doi.org/10.1016/S0140-6736(73)91539-0.

9. Reunala T, Blomqvist K, Tarpila S, Halme H, Kangas K. Glutenfree diet in dermatitis herpetiformis. I. Clinical response of skin lesions in 81 patients. Br J Dermatol. 1977;97:473-80. https:// doi.org/10.1111/j.1365-2133.1977.tb14122.x.

10. Reunala T, Salo OP, Tiilikainen A, Selroos O, Kuitunen P. Family studies in dermatitis herpetiformis. Ann Clin Res. 1976;8:254-61.
11. Balas A, Vicario JL, Zambrano A, Acuna D, Garcia-Novo D. Absolute linkage of celiac disease and dermatitis herpetiformis to HLA-DQ. Tissue Antigens. 1997;50:52-6. https://doi. org/10.1111/j.1399-0039.1997.tb02834.x.

12. Hervonen K, Karell A, Holopainen P, Collin P, Partanen J, Reunala T. Concordance of dermatitis herpetiformis and celiac disease in monozygous twins. J Invest Dermatol. 2000;115:990-3. https://doi.org/10.1046/j.1523-1747.2000.00172.x.

13. Leffler DA, Green PH, Fasano A. Extraintestinal manifestations of coeliac disease. Nat Rev Gastroenterol Hepatol. 2015;12:56171. https://doi.org/10.1038/nrgastro.2015.131.

14. Green PHR, Stavropoulos SN, Panagi SG, Goldstein SL, Mcmahon DJ, Absan H, Neugut AI. Characteristics of adult celiac disease in the USA: results of a national survey. Am J Gastroenterol. 2001;96:126-31. https://doi.org/10.111 1/j.1572-0241.2001.03462.x.

15. Dominguez Castro P, Harkin G, Hussey M, Christopher B, Kiat C, Chin JL, Trimble V, McNamara D, MacMathuna P, Egan B, Ryan B, Kevans D, Farrell R, Byrnes V, Mahmud V, McManus $\mathrm{R}$. Changes in presentation of celiac disease in Ireland from the 1960s to 2015. Clin Gastroenterol Hepatol. 2017;15:864-71. https://doi.org/10.1016/j.cgh.2016.11.018.

16. Kotze LM, Vecchia LA, Nisihara R, Kotze LR. Dermatitis herpetiformis in Brazilan male celiac disease patients: a case series. Rev Esp Enferm Dig. 2014;106:562-4.

17. Zhang F, Yang B, Lin Y, Chen S, Zhou G, Wang G, et al. Dermatitis herpetiformis in China: a report of 22 cases. J Eur Acad Dermatol Venereol. 2012;26:903-7. https://doi.org/10.111 1/j.1468-3083.2011.04204.x.

18. Handa S, Dabas G, De D, Mahajan R, Chatterjee D, Saika UN, Radotra BD. A retrospective study of dermatitis herpetiformis from an immunobullous disease clinic in north India. Int J Dermatol. 2018;57:959-64. https://doi.org/10.1111/ijd.14029.

19. Salmi TT, Hervonen K, Kautiainen H, Collin P, Reunala T. Prevalence and incidence of dermatitis herpetiformis: a 40-year prospective study from Finland. Br J Dermatol. 2011;165:354-9. https://doi.org/10.1111/j.1365-2133.2011.10385.x.

20. West J, Fleming KM, Tata LJ, Card TR, Crooks CJ. Incidence and prevalence of celiac disease and dermatitis herpetiformis in the UK over two decades: population-based study. Am J Gastroenterol. 2014;109:757-68. https://doi.org/10.1038/ajg.2014.55.

21. Lebwohl B, Sanders DS, Green PHR. Coeliac disease. Lancet. 2018;391:70-81. https://doi.org/10.1016/S0140-6736(17)31796 -8 .

22. Dieterich W, Ehnis T, Bauer M, Donner P, Volta U, Riecken EO, Schuppan D. Identification of tissue transglutaminase as the autoantigen of celiac disease. Nat Med. 1997;3:797-801. https:// doi.org/10.1038/nm0797-797.

23. Sárdy M, Kárpáti S, Merkl B, Paulsson M, Smyth N. Epidermal transglutaminase (TGase 3 ) is the autoantigen of dermatitis herpetiformis. J Exp Med. 2002;195:747-57. https://doi. org/10.1084/jem.20011299.

24. Sankari H, Hietikko M, Kurppa K, Kaukinen K, Mansikka E, Huhtala H, Laurila K, Reunala T, Hervonen K, Salmi T, Lindfors $\mathrm{K}$. Intestinal transglutaminase 3- and transglutaminase 2-specific plasma cell responses in dermatitis herpetiformis patients undergoing a gluten challenge. Nutrients. 2020;2020:12. https://doi. org/10.3390/nu12020467.

25. Reunala T, Salmi TT, Hervonen K, Laurila K, Kautiainen H, Collin P, Kaukinen K. IgA anti-epidermal transglutaminase antibodies in dermatitis herpetiformis: a significant but not complete response to a gluten-free diet treatment. Br J Dermatol. 2015;172:1139-41. https://doi.org/10.1111/bjd.13387.

26. Görög A, Németh K, Kolev K, Zone JJ, Mayer B, Silló P, Bognár P, Kárpáti S. Circulating transglutaminase 3-Immunoglobulin A immune complexes in dermatitis ferpetiformis. $\mathrm{J}$ 
Invest Dermatol. 2016;136:1729-31. https://doi.org/10.1016/j. jid.2016.03.039.

27. Taylor TB, Schmidt LA, Meyer LJ, Zone JJ. Transglutaminase 3 present in the $\operatorname{IgA}$ aggregates in dermatitis herpetiformis skin is enzymatically active and binds soluble fibrinogen. $\mathrm{J}$ Invest Dermatol. 2015;135:623-5. https://doi.org/10.1038/jid.2014.368.

28. Bolotin D, Petronic-Rosic V. Dermatitis herpetiformis: part II. Diagnosis, management, and prognosis. J Am Acad Dermatol. 2011;64:1027-33. https://doi.org/10.1016/j.jaad.2010.09.776.

29. Collin P, Reunala T. Recognition and management of the cutaneous manifestations of celiac disease: a guide for dermatologists. Am J Clin Dermatol. 2003;4:13-20. https://doi. org/10.2165/00128071-200304010-00002.

30. Alakoski A, Hervonen K, Mansikka E, Reunala T, Kaukinen K, Kivelä L, Laurikka P, Huhtala H, Kurppa K, Salmi T. The long-term safety and quality of life effects of oats in dermatitis herpetiformis. Nutrients. 2020;12:1060. https://doi.org/10.3390/ nu12041060.

31. Spijkerman M, Tan IJ, Kolkman JJ, Withoff S, Wijmenga C, Wisschedijk MC, Weersma RK. A large variety of clinical features and concomitant disorders in coeliac disease-a cohort study in the Netherlands. Dig Liver Dis. 2016;48:499-505. https://doi. org/10.1016/j.dld.2016.01.006.

32. Kulczycka-Siennicka L, Cynkier A, Waszczykowska E, Woźniacka A, Żebrowska A. The Role of Intereukin-31 in pathogenesis of itch and its intensity in a course of bullous pemphigoid and dermatitis herpetiformis. Biomed Res Int. 2017;2017:5965492. https://doi.org/10.1155/2017/5965492.

33. Griffiths CE, Leonard JN, Fry L. Dermatitis herpetiformis exacerbated by indomethacin. Br J Dermatol. 1985;112:443-5. https ://doi.org/10.1111/j.1365-2133.1985.tb02318.x.

34. Jimenez A, Hull C, Zone J. Dermatitis herpetiformis resistant to dapsone due to dietary iodide ingestion. JAAD Case Rep. 2019;5:713-4. https://doi.org/10.1016/j.jdcr.2019.06.011.

35. Kawakami Y, Oyama N, Nakamura K, Kaneko F. A case of loclized dermatitis herpetiformis on the face. J Am Acad Dermatol. 2008;58:S59-60. https://doi.org/10.1016/j.jaad.2006.06.012.

36. Karpati S, Torok E, Kosnai I. Discrete palmar and plantar symptoms in children with dermatitis herpetiformis Duhring. Cutis. 1986;37:184-7.

37. Tu H, Parmentier L, Stieger M, Spanou Z, Horn M, Beltraminelli $\mathrm{H}$, Borradori L. Acral purpura as leading clinical manifestation of dermatitis herpetiformis: report of two adult cases with a review of the literature. Dermatology. 2013;227:1-4. https:// doi.org/10.1159/000347108.

38. Venning V. Linear IgA disease: clinical presentation, diagnosis, and pathogenesis. Dermatol Clin. 2011;29:453-8. https://doi. org/10.1016/j.det.2011.03.013.

39. Amber KT, Murrell DF, Schmidt E, Joly P, Borradori L. Autoimmune subepidermal bullous diseases of the skin and mucosae: clinical features, diagnosis and management. Clin Rev Allergy Immunol. 2018;54:26-51. https://doi.org/10.1007/s 1201 6-017-8633-4.

40. Bolotin D, Petronic-Rosic V. Dermatitis herpetiformis. Part I. Epidemiology, pathogenesis, and clinical presentation. J Am Acad Dermatol. 2011;64:1017-24. https://doi.org/10.1016/j. jaad.2010.09.777.

41. Rose C, Bröcker E-B, Zillikens Z. Clinical, histological and immunopathological findings in 32 patients with dermatitis herpetiformis Duhring. J Dtsch Dermatol Ges. 2010;8:265-70. https://doi.org/10.1111/j.1610-0387.2009.07292.x.

42. Mansikka E, Salmi T, Kaukinen K, Collin P, Huhtala H, Reunala T, Hervonen K. Diagnostic delay in dermatitis herpetiformis in a high-prevalence area. Acta Derm Venereol. 2018;98:195-9. https://doi.org/10.2340/00015555-2818.
43. Fuchs V, Kurppa K, Huhtala H, Collin P, Mäki M, Kaukinen K. Factors associated with long diagnostic delay in celiac disease. Scand J Gastroenterol. 2014;49:1304-10. https://doi. org/10.3109/00365521.2014.923502.

44. Collin P, Huhtala H, Virta L, Kekkonen L, Reunala T. Diagnosis of celiac disease in clinical practice: physician's alertness to the condition essential. J Clin Gastroenterol. 2007;41:152-6. https://doi.org/10.1097/01.mcg.0000212618.12455.a8.

45. Rampertab D, Pooran N, Brar P, Singh P, Green PH. Trends in the presentation of celiac disease. Am J Med. 2006;119:35565. https://doi.org/10.1016/j.amjmed.2005.08.044.

46. Reunala T, Kosnai I, Karpati S, Kuitunen P, Török E, Savilahti E. Dermatitis herpetiformis: jejunal findings and skin response to gluten free diet. Arch Dis Child. 1984;59:517-22. https:// doi.org/10.1136/adc.59.6.517.

47. Ermacora E, Prampolini L, Tribbia G, Pezzoli G, Gelmetti C, Cucchi G, Tettamanti A, Giunta A, Gianotti F. Long-term follow-up of dermatitis herpetiformis in children. J Am Acad Dermatol. 1986;15:24-30. https://doi.org/10.1016/s0190 -9622(86)70137-0.

48. Buckley DB, English J, Molloy W, Doyle CT, Whelton MJ. Dermatitis herpetiformis: a review of 119 cases. Clin Exp Dermatol. 1983;8:477-87. https://doi.org/10.1111/j.1365-2230.1983.tb018 15.x.

49. Garioch JJ, Lewis HM, Sargent SA, Leonard JN, Fry L. 25 years' experience of a gluten-free diet in the treatment of dermatitis herpetiformis. Br J Dermatol. 1994;131:541-5. https://doi. org/10.1111/j.1365-2133.1994.tb08557.x.

50. Alonso-Llamazares J, Gibson LE, Rogers RS 3rd. Clinical, pathologic, and immunopathologic features of dermatitis herpetiformis: review of the Mayo Clinic experience. Int J Dermatol. 2007;46:910-9. https://doi.org/10.1111/j.1365-4632.2007.03214 .x.

51. Hervonen K, Salmi TT, Kurppa K, Kaukinen K, Collin P, Reunala T. Dermatitis herpetiformis in children: a long-term follow-up study. Br J Dermatol. 2014;171:1242-3. https://doi. org/10.1111/bjd.13047.

52. Antiga E, Verdelli A, Calabri A, Fabbri P, Caproni M. Clinical and immunopathological features of 159 patients with dermatitis herpetiformis: an Italian experience. G Ital Dermatol Venereol. 2013;148:163-9.

53. Reunala T, Salmi TT, Hervonen K, Kaukinen K, Collin P. Dermatitis herpetiformis: a common extraintestinal manifestation of coeliac disease. Nutrients. 2018;10:602. https://doi.org/10.3390/ nu10050602.

54. Zone JJ, Meyer LJ, Petersen MJ. Deposition of granular IgA relative to clinical lesions in dermatitis herpetiformis. Arch Dermatol. 1996;132:912-8. https://doi.org/10.1001/archd erm.1996.03890320060010.

55. Makino T, Shimizu T. Fibrillar-type dermatitis herpetiformis. Eur J Dermatol. 2019;29:115-20. https://doi.org/10.1684/ ejd.2019.3533.

56. Pierard J, Whimster I. The histological diagnosis of dermatitis herpetiformis, bullous pemphigoid and erythema multiforme. Br J Dermatol. 1961;73:253-66. https://doi. org/10.1111/j.1365-2133.1961.tb14442.x.

57. Blenkinsopp WK, Haffenden GP, Fry L, Leonard JN. Histology of linear IgA disease, dermatitis herpetiformis, and bullous pemphigoid. Am J Dermatopathol. 1986;5:547-54. https://doi. org/10.1097/00000372-198312000-00005.

58. Bresler SC, Granter SR. Utility of direct immunofluorescence testing for $\operatorname{IgA}$ in patients with high and low clinical suspicion for dermatitis herpetiformis. Am J Clin Pathol. 2015;144:880-4. https://doi.org/10.1309/AJCPXIVSR6OZK1HU.

59. Caproni M, Antiga E, Melani L, Fabbri P. Guidelines for the diagnosis and treatment of dermatitis herpetiformis. J Eur Acad 
Dermatol Venereol. 2009;23:633-8. https://doi.org/10.111 1/j.1468-3083.2009.03188.x.

60. Leonard J, Haffenden G, Tucker W, Unsworth J, Swain F, McMinn R, Holborow J, Fry L. Gluten challenge in dermatitis herpetiformis. N Engl J Med. 1983;308:816-9. https://doi. org/10.1056/NEJM198304073081406.

61. Salmi TT, Hervonen K, Kurppa K, Collin P, Kaukinen K, Reunala T. Celiac disease evolving into dermatitis herpetiformis in patients adhering to normal or gluten-free diet. Scand J Gastroenterol. 2015;50:387-92. https://doi.org/10.3109/00365 521.2014 .974204$.

62. Rodrigo L, Beteta-Gorriti V, Alvarez N, de Castro CG, de Dios A, Palacios L, Santos-Juanes J. Cutaneous and mucosal manifestations associated with celiac disease. Nutrients. 2018;10:800. https://doi.org/10.3390/nu10070800.

63. Bonciolini V, Antiga E, Bianchi B, Del Bianco E, Ninci A, Maio V, Pimpinelli N, Caproni M. Granular IgA deposits in the skin of patients with coeliac disease: is it always dermatitis herpetiformis? Acta Derm Venereol. 2019;99:78-83. https://doi. org/10.2340/00015555-3001.

64. Pasternack C, Kaukinen K, Kurppa K, Mäki M, Collin P, Hervonen K, Reunala T, Huhtala H, Kekkonen L, Salmi T. Gastrointestinal symptoms increase the burden of illness in dermatitis herpetiformis: a prospective study. Acta Derm Venereol. 2017;97:58-62. https://doi.org/10.2340/00015555-2471.

65. Mansikka E, Hervonen K, Salmi TT, Kautiainen H, Kaukinen $\mathrm{K}$, Collin P, Reunala T. The decreasing prevalence of severe villous atrophy in dermatitis herpetiformis: a 45-year experience in 393 patients. J Clin Gastroenterol. 2017;51:235-9. https://doi. org/10.1097/MCG.0000000000000533.

66. Mansikka E, Hervonen K, Kaukinen K, Collin P, Huhtala H, Reunala T. Prognosis of dermatitis herpetiformis patients with and without villous atrophy at diagnosis. Nutrients. 2018;10:641. https://doi.org/10.3390/nu10050641.

67. Dieterich W, Schuppan D, Laag E, Bruckner-Tuderman L, Reunala T, Kárpáti S, Zágoni T, Riecken EO, Schuppan D. Antibodies to tissue transglutaminase as serologic markers in patients with dermatitis herpetiformis. J Invest Dermatol. 1999;113:1336. https://doi.org/10.1046/j.1523-1747.1999.00627.x.

68. Leffler DA, Schuppan D. Update on serologic testing in celiac disease. Am J Gastroenterol. 2010;105:2520-4. https://doi. org/10.1038/ajg.2010.276.

69. Dahlbom I, Korponay-Szabo IR, Kovács JB, Szalai Z, Mäki M, Hansson T. Prediction of clinical and mucosal severity of coeliac disease and dermatitis herpetiformis by quantification of $\mathrm{IgA} / \mathrm{IgG}$ serum antibodies to tissue transglutaminase. J Pediatr Gastroenterol Nutr. 2010;50:140-6. https://doi.org/10.1097/MPG.0b013 e3181a81384.

70. Hull CM, Liddle M, Hansen N, Meyer LJ, Schmidt L, Taylor T, Jaskowski TD, Hill HR, Zone JJ. Elevation of IgA antiepidermal transglutaminase antibodies in dermatitis herpetiformis. Br J Dermatol. 2008;159:120-4. https://doi.org/10.111 1/j.1365-2133.2008.08629.x.

71. Singh P, Arora S, Lal S, Strand TA, Makharia GK. Risk of celiac disease in the first- and second-degree relatives of patients with celiac disease: a systematic review and meta-analysis. Am J Gastroenterol. 2015;110:1539-48. https://doi.org/10.1038/ ajg.2015.296.

72. Hervonen K, Hakanen M, Kaukinen K, Collin P, Reunala K. First-degree relatives are frequently affected in coeliac disease and dermatitis herpetiformis. Scand J Gastroenterol. 2002;37:515. https://doi.org/10.1080/003655202753387356.

73. Meyer LJ, Zone JJ. Familial incidence of dermatitis herpetiformis. J Am Acad Dermatol. 1987;17:643-7. https://doi. org/10.1016/s0190-9622(87)70250-3.
74. Ciacci C, Ciclitira P, Hadjivassiliou M, Kaukinen K, Ludvigsson JF, McGough N, Sanders DS, Woodward J, Leonard JN, Swift GL. The gluten-free diet and its current application in coeliac disease and dermatitis herpetiformis. United Eur Gastroenterol J. 2015;3:121-35. https://doi.org/10.1177/2050640614559263.

75. Hardman CM, Garioch JJ, Leonard JN, Thomas HJ, Walker MM, Lortan JE, Lister A, Fry L. Absence of toxicity of oats in patients with dermatitis herpetiformis. N Engl J Med. 1997;3378:1884-7. https://doi.org/10.1056/NEJM199712253372604.

76. Reunala T, Collin P, Holm K, Pikkarainen P, Miettinen A, Vuolteenaho N, Mäki M. Tolerance to oats in dermatitis herpetiformis. Gut. 1998;43:490-3. https://doi.org/10.1136/ gut.43.4.490.

77. Ludvigsson JF, Card T, Ciclitira PJ, Swift GL, Nasr I, Sanders DS, Ciacci C. Support for patients with celiac disease: a literature review. United Eur Gastroenterol J. 2015;3:146-59. https://doi. org/10.1177/2050640614562599.

78. Mansikka E, Hervonen K, Kaukinen K, Ilus T, Oksanen P, Lindfors K, Laurila K, Hietikko M, Taavela J, Jernman J, Saavalainen $\mathrm{P}$, Reunala T, Salmi T. Gluten challenge induces skin and small bowel relapse in long-term gluten-free diet-treated dermatitis herpetiformis. J Invest Dermatol. 2019;139:2108-14. https:// doi.org/10.1016/j.jid.2019.03.1150.

79. Rubio-Tapia A, Rahim MW, See JA, Lahr BD, Wu TT, Murray JA. Mucosal recovery and mortality in adults with celiac disease after treatment with a gluten-free diet. Am J Gastroenterol. 2010;105:1412-20. https://doi.org/10.1038/ajg.2010.10.

80. Hervonen K, Alakoski A, Salmi TT, Helakorpi S, Kautiainen H, Kaukinen K, Pukkala E, Collin P, Reunala T. Reduced mortality in dermatitis herpetiformis: a population-based study of 476 patients. Br J Dermatol. 2012;167:1331-7. https://doi.org/10.11 11/j.1365-2133.2012.11105.x.

81. Zhu YI, Stiller MJ. Dapsone and sulfones in dermatology. Overview and update. J Am Acad Dermatol. 2001;45:420-34. https ://doi.org/10.1067/mjd.2001.114733.

82. Hervonen K, Salmi T, Ilus T, Paasikivi K, Vornanen M, Laurila K, Lindfors K, Viiri K, Saavalainen P, Collin P, Kaukinen K, Reunala T. Dermatitis herpetiformis refractory to gluten free dietary treatment. Acta Derm Venereol. 2016;96:82-6. https:// doi.org/10.2340/00015555-2184.

83. Waldinger TP, Siegle RJ, Weber W, Voorhees JJ. Dapsoneinduced peripheral neuropathy. Case report and review. Arch Dermatol. 1984;120:356-9.

84. Albers LN, Zone JJ, Stoff BK, Feldman RJ. Rituximab treatment for recalcitrant dermatitis herpetiformis. JAMA Dermatol. 2017;153:315-8. https://doi.org/10.1001/jamadermat ol.2016.4676.

85. Handler MZ, Chacon AH, Shiman MI, Schachner LA. Letter to the editor: application of dapsone $5 \%$ gel in a patient with dermatitis herpetiformis. J Dermatol Case Rep. 2012;6:132-3. https://doi.org/10.3315/jdcr.2012.1124.

86. Cinats AK, Parsons LM, Haber RM. Facial involvement in dermatitis herpetiformis: a case report and review of the literature. J Cutan Med Surg. 2019;23:35-7. https://doi.org/10.1177/12034 75418795818.

87. Lewis HM, Renuala TL, Garioch JJ, Leonard JN, Fry JS, Collin P, Evans D, Fry L. Protective effect of gluten-free diet against development of lymphoma in dermatitis herpetiformis. Br J Dermatol. 1996;135:363-7.

88. Tio M, Cox MR, Eslick GD. Meta-analysis: coeliac disease and the risk of all-cause mortality, any malignancy and lymphoid malignancy. Aliment Pharmacol Ther. 2012;35:540-51. https:// doi.org/10.1111/j.1365-2036.2011.04972.x.

89. Hervonen K, Vornanen M, Kautiainen H, Collin P, Reunala T. Lymphoma in patients with dermatitis herpetiformis and their 
first-degree relatives. Br J Dermatol. 2005;152:82-6. https://doi. org/10.1111/j.1365-2133.2005.06345.x.

90. Lewis NR, Logan RF, Hubbard RB, West J. No increase in risk of fracture, malignancy or mortality in dermatitis herpetiformis: a cohort study. Aliment Pharmacol Ther. 2008;27:1140-7. https ://doi.org/10.1111/j.1365-2036.2008.03660.x.

91. Hervonen K, Viljamaa M, Collin P, Knip M, Reunala T. The occurrence of type 1 diabetes in patients with dermatitis herpetiformis and their first-degree relatives. Br J Dermatol. 2004;150:136-8. https://doi.org/10.111 1/j.1365-2133.2004.05642.x.

92. Kárpáti S, Kósnai I, Verkasalo M, Kuitunen P, Simon Z, Koskimies S, Reunala T, Gyódi E, Török E. HLA antigens, jejunal morphology and associated diseases in children with dermatitis herpetiformis. Acta Paediatr Scand. 1986;75:297-301. https:// doi.org/10.1111/j.1651-2227.1986.tb10202.x.

93. Kauppi S, Jokelainen J, Timonen M, Tasanen K, Huilaja L. Atopic dermatitis is associated with dermatitis herpetiformis and celiac disease in children. J Invest Dermatol. 2020. https:// doi.org/10.1016/j.jid.2020.05.091.

94. Cunningham MJ, Zone JJ. Thyroid abnormalities in dermatitis herpetiformis. Prevalence of clinical thyroid disease and thyroid autoantibodies. Ann Intern Med. 1985;102:194-6. https://doi. org/10.7326/0003-4819-102-2-194.

95. Reunala T, Collin P. Diseases associated with dermatitis herpetiformis. Br J Dermatol. 1997;136:315-8.
96. Varpuluoma O, Jokelainen J, Försti AK, Timonen M, Huilaja L, Tasanen K. Dermatitis herpetiformis and celiac disease increase the risk of bullous pemphigoid. J Invest Dermatol. 2019;139:600-4. https://doi.org/10.1016/j.jid.2018.10.010.

97. Pasternack C, Kaukinen K, Kurppa K, Mäki M, Collin P, Reunala T, Huhtala H, Salmi T. Quality of life and gastrointestinal symptoms in long-term treated dermatitis herpetiformis patients: a cross sectional study in Finland. Am J Clin Dermatol. 2015;16:545-52. https://doi.org/10.1007/s40257-015-0149-1.

98. Burger JPW, de Brouwer B, IntHout J, Wahab PJ, Tummers M, Drenth JPH. Systematic review with meta-analysis: dietary adherence influences normalization of health-related quality of life in coeliac disease. Clin Nutr. 2017;36:399-406. https://doi. org/10.1016/j.clnu.2016.04.021.

99. Ludvigsson JF, Murray JA. Epidemiology of celiac disease. Gastroenterol Clin North Am. 2019;48:1-18. https://doi. org/10.1016/j.gtc.2018.09.004.

100. Hietikko M, Hervonen K, Salmi T, Ilus T, Zone JJ, Kaukinen K, Reunala T, Lindfors K. Disappearance of epidermal transglutaminase and IgA deposits from the papillary dermis of patients with dermatitis herpetiformis after a long-term gluten-free diet. Br J Dermatol. 2018;178:e198-201. https://doi.org/10.1111/ bjd.15995. 